\title{
Energy Consumption, Carbon Emissions and Global Warming Potential of Wolfberry Production in Jingtai Oasis, Gansu Province, China
}

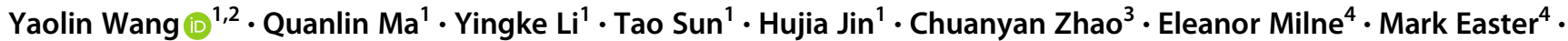 \\ Keith Paustian ${ }^{4} \cdot$ Hoi Wen Au Yong ${ }^{5} \cdot$ John McDonagh ${ }^{5}$
}

Received: 29 March 2018 / Accepted: 11 November 2019 / Published online: 20 November 2019

(c) The Author(s) 2019

\begin{abstract}
During the last decade, China's agro-food production has increased rapidly and been accompanied by the challenge of increasing greenhouse gas (GHG) emissions and other environmental pollutants from fertilizers, pesticides, and intensive energy use. Understanding the energy use and environmental impacts of crop production will help identify environmentally damaging hotspots of agro-production, allowing environmental impacts to be assessed and crop management strategies optimized. Conventional farming has been widely employed in wolfberry (Lycium barbarum) cultivation in China, which is an important cash tree crop not only for the rural economy but also from an ecological standpoint. Energy use and global warming potential (GWP) were investigated in a wolfberry production system in the Yellow River irrigated Jingtai region of Gansu. In total, 52 household farms were randomly selected to conduct the investigation using questionnaires. Total energy input and output were $321,800.73$ and $166,888.80 \mathrm{MJ} \mathrm{ha}^{-1}$, respectively, in the production system. The highest share of energy inputs was found to be electricity consumption for lifting irrigation water, accounting for $68.52 \%$, followed by chemical fertilizer application (11.37\%). Energy use efficiency was 0.52 when considering both fruit and pruned wood. Nonrenewable energy use $(88.52 \%)$ was far larger than the renewable energy input. The share of GWP of different inputs were $64.52 \%$ electricity, $27.72 \%$ nitrogen $(\mathrm{N})$ fertilizer, $5.07 \%$ phosphate, $2.32 \%$ diesel, and $0.37 \%$ potassium, respectively. The highest share was related to electricity consumption for irrigation, followed by $\mathrm{N}$ fertilizer use. Total GWP in the wolfberry planting system was $26,018.64 \mathrm{~kg} \mathrm{CO}_{2}$ eq ha ${ }^{-1}$ and the share of $\mathrm{CO}_{2}, \mathrm{~N}_{2} \mathrm{O}$, and $\mathrm{CH}_{4}$ were $99.47 \%, 0.48 \%$, and negligible respectively with $\mathrm{CO}_{2}$ being dominant. Pathways for reducing energy use and GHG emission mitigation include: conversion to low carbon farming to establish a sustainable and cleaner production system with options of raising water use efficiency by adopting a seasonal gradient water pricing system and advanced irrigation techniques; reducing synthetic fertilizer use; and policy support: smallholder farmland transfer (concentration) for scale production, credit (small- and lowinterest credit) and tax breaks.
\end{abstract}

Keywords Energy use $\cdot$ Greenhouse gas emissions $\cdot$ Global warming potential $\cdot$ Wolfberry plantation

Yaolin Wang

wangylgs@126.com

1 State Key Laboratory of Desertification and Aeolian Sand Disaster Combating, Gansu Desert Control Research Institute, Lanzhou, China

2 Tianshui Normal University, Tianshui, China
3 State Key Laboratory of Grassland and Agro-Ecosystems, School of Pastoral Agriculture, Lanzhou University, Lanzhou 730000, China

4 The Natural Resource Ecology Laboratory, Colorado State University, Fort Collins, CO 80523-1499, USA

5 School of International Development, University of East Anglia, Norwich NR4 7TJ, UK 


\section{Introduction}

Global greenhouse gas (GHG) emissions from food production nearly doubled during the period between 1961 and 2011 (FAOSTAT 2014), and will continue to rise as global crop demand is projected to have a $100-110 \%$ increase between 2005 and 2050 (Tilman et al. 2011). This alarming increase is closely correlated with intensive energy use. Agriculture is one of the major energy consumers and has experienced rapid intensification in recent decades (Nemecek et al. 2011). The production, transportation, processing, etc. of the agro-food sector contributes $20 \%$ to global anthropogenic GHG emissions (FAO 2012). Notably, emissions from agricultural production account for over $80-86 \%$ of the global total food system emissions (Vermeulen et al. 2012). Recent studies have suggested that the agro-food sector is a significant contributor to global warming (Beccali et al. 2009; Michos et al. 2012).

As the largest food producer and consumer in the world, China has been one of the largest anthropogenic GHG emitters and currently emits around $20 \%$ of global GHGs (Leggett et al. 2011). Agricultural GHG emissions have been estimated at $11 \%$ of China's national emissions, growing rapidly from $605 \mathrm{Mt} \mathrm{CO}_{2}$ eq in 1994 to $820 \mathrm{Mt}$ $\mathrm{CO}_{2}$ eq in 2005 with a mean annual growth rate of $2.8 \%$ (Nayak et al. 2015; Lin et al. 2015). China is also the largest chemical fertilizer consumer with a $\mathrm{N}_{2} \mathrm{O}$ emissions increase from $0.18 \mathrm{Tg}$ in 1978 to $0.41 \mathrm{Tg}$ in 2010 (Cui et al. 2013).

The Chinese government made a commitment at the 2009 U.N. Climate Change Conference in Copenhagen that, by 2020 , China's $\mathrm{CO}_{2}$ emissions will drop with a target of 40-45\% above the emission level in 2005 (Yang and Chen 2013). Agriculture is among the major sectors earmarked to reduce energy use while low carbon approaches in crop production is part of China's national climate change mitigation strategy. Accordingly, Gansu province has been designated as a circular economic demonstration area in China and low carbon and organic farming initiatives are a key area to attain green growth (Deng 2014).

Cash tree production has increased rapidly in China over the last decade, making it one of the largest fruit producers

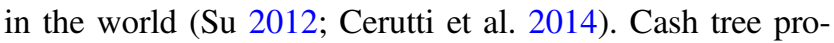
duction is an intensive agricultural system with high inputs of fertilizers, pesticides, irrigation, fossil fuels, and other materials ( $\mathrm{Li}$ et al. 2010). However, growers are generally motivated by the notion of "the more fertilizer and irrigation, the higher the yield output," instead of energy efficiency and judicious management, with extensive management as a result, causing environmental issues (Cao 2014; Jiao et al. 2016). Efficient energy use in agriculture would minimize environmental burdens, decrease reliance on nonrenewable energy, and form a sustainable and economical production system (Uhlin 1998). In recent years, many studies have been conducted to determine the energy use pattern and efficiency of cash tree production; for example apple production in Greece (Strapatsa et al. 2006), energy inputs, outputs, and GHG emissions in organic, integrated and conventional peach orchards (Michos et al. 2012), resource consumption and emissions in olive oil production (Avraamides and Fatta 2008), environmental impacts in citrus production (Dwivedi et al. 2012) and energy use and GHG emissions in almond production in the United States (Kendall et al. 2015). Liu et al (2010a) compared carbon footprints of organic and conventional pear planting in northern China using life cycle analysis and indicated options available to reduce energy use and carbon emissions. In addition, Wang et al (2015) assessed the impact of diversified management practices of winter wheat on total GHG emissions.

Wolfberry (Lycium barbarum L.), is a shrub with its fruits being served as tonic food and traditional Chinese medicine, sold not only in domestic market but also exported to other countries and regions with good and stable prices ( $\mathrm{Li}$ et al. 2017). It is salt tolerant, drought resistant, fast-growing, and fruits in the first year of planting. It is widely used for saline land improvement and rural economic development. Thus the area under wolfberry cultivation has expanded in northern China over the last few decades. However, there is little information on energy use efficiency and global warming potential (GWP) in wolfberry production systems in China.

Therefore, a combination of energy input and environmental impact analysis in a production system is necessary to optimize crop management practices, reduce the environmental impacts and promote sustainable development (Ming et al. 2015). The objectives of this study were to: (i) analyze the output-input energy; (ii) calculate total GHG emissions $\left(\mathrm{CO}_{2}, \mathrm{~N}_{2} \mathrm{O}\right.$, and $\left.\mathrm{CH}_{4}\right)$, and (iii) determine GWP per unit of chemical input and output in a wolfberry production system in Gansu, with the aim of identifying possible pathways to reducing energy consumption and mitigating environmental impacts in cash tree crop production.

\section{Materials and Methods}

The study was conducted in wolfberry plantations in the full bearing period in the irrigated area of Jingtai County $\left(103^{\circ}\right.$ $33^{\prime}-104^{\circ} 43^{\prime}$ E, $36^{\circ} 43^{\prime}-37^{\circ} 28^{\prime} \mathrm{N}$ ) in northern Gansu Province, northwest China in 2013-2014. Jingtai County is one of the main wolfberry producers in Gansu. The region has a dry continental climate with an average annual temperature of about $8.6{ }^{\circ} \mathrm{C}$, a maximum temperature of $38.6{ }^{\circ} \mathrm{C}$ in July and a minimum temperature of $-27.3^{\circ} \mathrm{C}$ in January. Annual rainfall is $\sim 180 \mathrm{~mm}$, of which $90 \%$ falls between April and September. 
Table 1 The main field management activities involved in wolfberry planting in Jingtai, Gansu, China

\begin{tabular}{|c|c|c|}
\hline Field operations & Time & Brief frequency or intensity description \\
\hline \multirow[t]{3}{*}{ Fertilizer application } & Beginning of March & $\begin{array}{l}\text { Apply sheep manure }{ }^{\mathrm{a}}\left(N=0.65 \%, \mathrm{P}_{2} \mathrm{O}_{5}=\right. \\
\left.0.47 \%, \mathrm{~K}_{2} \mathrm{O}=0.21 \%\right) \text { by spade }\end{array}$ \\
\hline & $\begin{array}{l}\text { Beginning of March, beginning of May, be gaining of June, } \\
\text { middle of July. }\end{array}$ & Apply chemical fertilizers by spade \\
\hline & End of May, end of June, middle of July & Spray $\mathrm{KH}_{2} \mathrm{PO}_{4}$ with tricycle driven sprayer \\
\hline $\begin{array}{l}\text { Pruning (winter, spring, and } \\
\text { summer) }\end{array}$ & $\begin{array}{l}\text { Beginning of December to end of March, middle to end of May, } \\
\text { and end of May to end of June }\end{array}$ & $\begin{array}{l}\text { Pruning with special scissors with heavy } \\
\text { winter pruning }\end{array}$ \\
\hline \multirow[t]{2}{*}{ Weeding } & Before middle of May & By tiller rotary \\
\hline & After middle of May & Spray herbicides by sprayer manually \\
\hline Irrigation & After end of April to end of October & 8 times per year \\
\hline Pest management & Growing season & $\begin{array}{l}\text { Spray chemical pesticides } 6 \text { times with tricycle } \\
\text { driven sprayer }\end{array}$ \\
\hline Harvesting & Middle of June to beginning of September & By hand \\
\hline Fruit air drying & Harvesting season & By hand \\
\hline
\end{tabular}

${ }^{\mathrm{a}} \mathrm{He}$ et al. 2011

The region's agriculture strongly depends on irrigation by an electrically powered water lifting project from the Yellow River with a total lift of $713 \mathrm{~m}$. Wolfberry cultivation is managed on a household farm basis. Most of households in the irrigated region are engaged mainly in wolfberry cultivation and the region is the origin of wolfberry cultivation in Gansu. The plantation size across households ranges from 0.3 to 3 ha and the planting density is 5250 trees $\mathrm{ha}^{-1}$. The main field management activities are given in Table 1. Wolfberry growing has stimulated processing, trade and job opportunities, becoming a pillar of the local economy (Zhang et al. 2010). Meanwhile, based on wolfberry planting a new ecological agriculture model is taking shape, namely, free range chicken production within the plantation (Sheng and Su 2011).

The investigation was carried out in 52 household farms, selected with the simple random sampling method (Fan et al. 2016) in Jingtai's wolfberry planting region. Data on farm practices, inputs, and consumption of resources at each stage of the production chain were collected with a household survey questionnaire via face-face interviews. In addition, information was also collected from local Forestry Bureau, Forestry and Agricultural Technical Extension Stations and Agricultural Machinery Service.

The fruit yield and pruning wood were designated as the energy output. The energy inputs included human labor, machinery, diesel fuel, chemical fertilizers, pesticides, electricity, and irrigation water. Input energy in wolfberry production systems can be divided into direct, indirect, and renewable and nonrenewable energies. Direct energy in the study system involved human labor, diesel fuel, water for irrigation, and electricity. Indirect energy included chemical fertilizer, manure, pesticide, machinery, and tools. Also, renewable energy resources were human labor, water for irrigation, and manure and nonrenewable energy resources were electricity, chemical fertilizer, diesel fuel, pesticide, machinery, and tools.

All of the inputs and outputs were converted into energy equivalents by multiplying the quantity of inputs by their corresponding energy coefficients. The energy equivalents of inputs used in this study are given in Table 2. The energy efficiency of wolfberry production was evaluated based on the input-output analysis. For the estimation of fossil energy used in wolfberry planting, both direct (fossil energy consumed on the farm) and indirect energy (fossil energy for production of synthetic fertilizers, chemical pesticides, machinery, etc.), were considered. In addition, the energy input of human labor was considered. The energy equivalent of water for irrigation input means indirect energy of irrigation consisting of the energy consumed for manufacturing the materials for the dams, canals, pipes, pumps, and equipment as well as the energy for constructing the works and building the on-farm irrigation systems (Khan et al. 2009). Embodied energy in machinery was expressed in terms of $\mathrm{MJ} \mathrm{kg}^{-1}$. To analyze embodied energy in the production of farm machinery, it was assumed that energy is depreciated during the economic lifetime of the machinery (Iriarte et al. 2010); Eq. (1) was used to calculate the weight of machinery depreciated per hectare of wolfberry production during the production period (Mousaviavval et al. 2011):

$$
T W=G \times W_{h} / T
$$

where $T W$ denotes the depreciated machinery weight $\left(\mathrm{kg} \mathrm{ha}^{-1}\right) ; G$ refers to the total machine weight $(\mathrm{kg}) ; W_{h}$ stands for the time of machine use per unit area $\left(\mathrm{h} \mathrm{ha}^{-1}\right)$ and $T$ is the economic lifetime of machine (h). 
Table 2 Energy equivalents of inputs and outputs

\begin{tabular}{lllll}
\hline Inputs and output $\quad$ Unit & $\begin{array}{l}\text { Energy equivalent } \\
\left(\mathrm{MJ} \mathrm{unit}^{-1}\right)\end{array}$ & Mass (kg) Life (years) & Reference
\end{tabular}
$\left(\mathrm{MJ}\right.$ unit $^{-1}$ )

\begin{tabular}{|c|c|c|c|}
\hline \multicolumn{4}{|l|}{ A. Inputs } \\
\hline 1. Human labor & $\mathrm{h}$ & 1.95 & \\
\hline 2. Machinery & $\mathrm{kg}$ & 210.00 & \\
\hline (a) Sprayer & & & 7.00 \\
\hline (b) Rotary tiller & & & 70.00 \\
\hline (c) Agricultural tricycle & & & 1120.00 \\
\hline
\end{tabular}

$\begin{array}{llr}\text { 3. Diesel fuel } & \mathrm{L} & 47.79 \\ \text { 4. Chemical fertilizer } & & \\ \text { (a) Nitrogen }(\mathrm{N}) & \mathrm{kg} & 50.00 \\ \text { (b) Phosphate }\left(\mathrm{P}_{2} \mathrm{O}_{5}\right) & \mathrm{kg} & 12.00 \\ \text { (c) Potassium }\left(\mathrm{K}_{2} \mathrm{O}\right) & \mathrm{kg} & 4.22\end{array}$

5. Pesticides

$\begin{array}{llr}\text { (a) Herbicides } & \mathrm{kg} & 288.00 \\ \text { (c) Pesticides } & \mathrm{kg} & 237.00 \\ \text { 6. Farmyard manure } & \mathrm{kg} & 0.30 \\ \text { 7. Electricity } & \mathrm{kWh} & 12.50 \\ \text { 8. Water for irrigation } & \mathrm{m}^{3} & 1.02 \\ \text { 9. Tools (scissors, hoes, } & \mathrm{h} & 0.10 \\ \text { spades, etc.) } & & \end{array}$

(Liu et al. 2010a)

(Liu et al. 2010a)

(Kizilaslan 2009)

(Liu et al. 2010a)

(Rajaeifar et al. 2014)

(Liu et al. 2010a)

B. Output
(a) Yield
$\mathrm{kg} \quad 18.36$
(Xu et al. 2007)
(b) Prunings
$\mathrm{kg} \quad 18.48$
(Liu 2011)

Table 3 Gaseous emissions (g) per unit of chemical sources and their global warming potential (GWP)

\begin{tabular}{lrrrr}
\hline Inputs & \multicolumn{1}{c}{$\mathrm{CO}_{2}$} & $\mathrm{~N}_{2} \mathrm{O}$ & \multicolumn{1}{c}{$\mathrm{CH}_{4}$} & Reference \\
\hline 1. Diesel (L) & 3875.70 & 0.14 & 0.65 & Yang et al. (2014) \\
2. Nitrogen fertilizer $(\mathrm{kg})$ & $10,125.56$ & 0.17 & 0.24 & Yang et al. (2014) \\
3. Phosphate $\left(\mathrm{P}_{2} \mathrm{O}_{5}\right)(\mathrm{kg})$ & 1496.49 & 0.02 & 0.02 & Yang et al. (2014) \\
4. Potassium $\left(\mathrm{K}_{2} \mathrm{O}\right)(\mathrm{kg})$ & 973.20 & 0.03 & 0.04 & Yang et al. (2014) \\
5. Electricity $(\mathrm{kW} \mathrm{h)}$ & 948.48 & 0.01 & 0.01 & Yang et al. (2014) \\
GWP CO $\mathrm{CO}_{2}$ equivalence factor & 1.00 & 298.00 & 25.00 & Yang et al. (2014)
\end{tabular}

Energy use efficiency, energy productivity, net energy, and specific energy were determined according to Eqs. (2-5), respectively, (Asgharipour et al. 2012):

Energy use efficiency $=$ Energy output

$$
\left(\mathrm{MJ} \mathrm{ha}^{-1}\right) / \text { Energy input }\left(\mathrm{MJ} \mathrm{ha}^{-1}\right)
$$

Energy productivity $=$ Crop output $\left(\mathrm{kg} \mathrm{ha}^{-1}\right) /$

$$
\text { Energy input }\left(\mathrm{MJ} \mathrm{ha}^{-1}\right)
$$

Net energy $=$ Energy output $\left(\mathrm{MJ} \mathrm{ha}^{-1}\right)$

$$
\text { -Energy input }\left(\mathrm{MJ} \mathrm{ha}^{-1}\right)
$$

Specific energy $=$ Energy input $\left(\mathrm{MJ} \mathrm{ha}^{-1}\right) /$

$$
\text { Yield }\left(\mathrm{kg} \mathrm{ha}^{-1}\right)
$$

The amount of GHG emissions from chemical inputs in wolfberry production per hectare were calculated by using $\mathrm{CO}_{2}, \mathrm{~N}_{2} \mathrm{O}$, and $\mathrm{CH}_{4}$ emissions coefficients of chemical inputs that are shown in Table 3. GHG emissions can be calculated and expressed in per unit land area, per unit crop produce, per unit energy input or output, and per unit economic output. In this study, the direct emissions from GHGs resulting from chemical inputs were calculated per unit cropland area. Each GHG, i.e., carbon dioxide $\left(\mathrm{CO}_{2}\right)$, methane $\left(\mathrm{CH}_{4}\right)$, and nitrous oxide $\left(\mathrm{N}_{2} \mathrm{O}\right)$ has a GWP, which is the warming influence relative to that of carbon dioxide. The emissions are measured in terms of a reference gas, $\mathrm{CO}_{2}$ (IPCC et al. 1995). The GWPs of $\mathrm{CO}_{2}, \mathrm{CH}_{4}$, andN $\mathrm{N}_{2} \mathrm{O}$ (with a time span of 100 years) are 1, 25, and 298, respectively. The total GHG effect related to emissions of 
GHGs is determined as follows (Kramer et al. 1999):

Greenhouse effect $=\Sigma \mathrm{GWP}_{\mathrm{i}} \times \mathrm{m}_{\mathrm{i}}$

where $\mathrm{m}_{\mathrm{i}}$ is the mass (in $\mathrm{kg}$ ) of the emission gas. The score is expressed in terms of $\mathrm{CO}_{2}$ equivalents.

\section{Results and Discussion}

\section{Energy Input-Output Analysis in Wolfberry Production}

Energy inputs and outputs in the wolfberry production system, their energy equivalents, and percentages in the total energy input are given in Table 4. The total energy input for wolfberry production was $321,800.7 \mathrm{MJ} \mathrm{ha}^{-1}$. The highest share in the total energy input was found to be electricity consumption for lifting water for irrigation accounting for $68.5 \%$, followed by chemical fertilizers use $11.37 \%$, chemicals $5.45 \%$, and human labor $5.16 \%$,

Table 4 Energy inputs, outputs, and the ratio in wolfberry production systems

\begin{tabular}{|c|c|c|c|}
\hline Inputs and output (unit) & $\begin{array}{l}\text { Quantity per } \\
\text { unit area (ha) }\end{array}$ & $\begin{array}{l}\text { Total energy } \\
\text { equivalents }\end{array}$ & $\%$ \\
\hline \multicolumn{4}{|l|}{ A. Inputs } \\
\hline 1. Human labor (h) & 8520.00 & $16,614.00$ & 5.16 \\
\hline 2. Machinery (kg) & 2915.50 & 2915.50 & 0.91 \\
\hline Sprayer & & 0 & 0 \\
\hline Rotary tiller & & 0 & 0 \\
\hline $\begin{array}{l}\text { Agricultural } \\
\text { tricycle }\end{array}$ & & 0 & 0 \\
\hline 3. Diesel fuel (L) & 147.00 & 7025.13 & 2.18 \\
\hline \multicolumn{4}{|l|}{ 4. Chemical fertilizer $(\mathrm{kg})$} \\
\hline Nitrogen $(\mathrm{N})$ & 546.00 & $27,300.00$ & 8.48 \\
\hline Phosphate $\left(\mathrm{P}_{2} \mathrm{O}_{5}\right)$ & 760.20 & 9122.40 & 2.83 \\
\hline Potassium $\left(\mathrm{K}_{2} \mathrm{O}\right)$ & 45.90 & 193.70 & 0.06 \\
\hline $\begin{array}{l}\text { 5. Farmyard } \\
\text { manure }(\mathrm{kg})\end{array}$ & $24,970.0$ & 7491.00 & 2.33 \\
\hline \multicolumn{4}{|l|}{ 6. Chemicals (kg) } \\
\hline Pesticides & 63.00 & $14,931.00$ & 4.64 \\
\hline Herbicides & 9 & 2592.00 & 0.81 \\
\hline 7. Electricity $(\mathrm{kW} \mathrm{h})$ & $17,640.0$ & $220,500.00$ & 68.52 \\
\hline $\begin{array}{l}\text { 8. Water for irrigation } \\
\left(\mathrm{M}^{3}\right)\end{array}$ & $12,600.00$ & $12,852.00$ & 3.99 \\
\hline $\begin{array}{l}\text { 9. Tools (scissors, hoes, } \\
\text { spades, etc.) }\end{array}$ & 2640.00 & 264.00 & 0.08 \\
\hline Total input energy & & $321,800.73$ & 100 \\
\hline \multicolumn{4}{|l|}{ B. Output } \\
\hline Yield (kg) & 4500.00 & $82,620.00$ & \\
\hline Prunings (kg) & 4560.00 & $84,268.80$ & \\
\hline Total output energy & & $166,888.80$ & \\
\hline
\end{tabular}

respectively. The wolfberry production system is characterized by high energy inputs in electricity use, fertilizer application, in particular nitrogen fertilizer. Beigi et al. (2015) reported the highest share of electricity (58\%) consumed for pumping water for irrigation in almond production in arid Tokan Province, Iran. Tabatabaie et al. (2012, 2013) showed a similar trend in plum (80\%) and pear $(78 \%)$ production in arid areas in Iran. High electricity consumption for water lifting from the Yellow River, with a high lift, is a salient feature of wolfberry planting in Jingtai region, caused by extravagant water use for irrigation due to poor irrigation efficiency as well as rigid water pricing, a policy based mechanism and a result of the planned economy. Current water prices are too low, about $51.1 \%$ of the cost price (Peng 2011). A water consumption of $12,600 \mathrm{~m}^{3} \mathrm{ha}^{-1}$ for irrigation has been adopted by growers in most cases so far, far beyond the irrigation water norm of $5550-6270 \mathrm{~m}^{3} \mathrm{ha}^{-1}$ for wolfberry (Zhang et al. 2010; Zeng et al. 2013), causing serious waste of water, second salinization of soil, high energy inputs, and increased GHG emissions, which has consequently led to a reduced sustainability of the production system.

Of the fertilizer energy input, the share of nitrogen fertilizer was the highest $(8.48 \%)$, incurred by heavy use and high embodied energy intensity; phosphate the second $(2.83 \%)$, and potassium the third $(0.06 \%)$. Nitrogen application makes up the highest share in the fertilizers energy input in apricot production in Turkey (Esengun et al. 2007). Similar trends have also been reported for pistachio, orange, and peach production respectively (Külekci and Aksoy 2013; Ozkan et al. 2004; Ghatrehsamani et al. 2016).

In terms of the chemicals energy input, the share of pesticides use was the highest $(4.64 \%)$ and herbicides input the second $(0.81 \%)$. A higher share of pesticides in the total input energy is also found in peach production system in Turkey (Yildiz et al. 2016).

Human labor, a renewable source of energy, was in the fourth place. Both fruit harvest and pruning consist of the bulk of the labor energy input with fruit harvest accounting for $60 \%$ and pruning for $13 \%$, respectively, in wolfberry production systems in Jingtai region (Wang et al. 2015). The highest use of human labor is also found in harvesting (56\%) and pruning operations $(23 \%)$ in apple production in Iran (Rafiee et al 2010) as well as in fruit harvest (46\%) in walnut production systems in Turkey (Gundogmus 2013).

The wolfberry fruit yield was $4500 \mathrm{~kg} \mathrm{ha}^{-1}$ on average and total brushwood pruned was $4560 \mathrm{~kg} \mathrm{ha}^{-1}$ in the production system. Accordingly, their energy equivalents were 82,620 and $84,268.8 \mathrm{MJ} \mathrm{ha}^{-1}$, respectively. Total energy output was calculated for both fruit and trimmings energy equivalents. Pruning is an important part of a wolfberry production system with a view to gaining a stable and high yield. Pruned wood is a byproduct of wolfberry planting, 
Table 5 Energy indices in wolfberry planting

\begin{tabular}{llr}
\hline Indicators & Unit & \multicolumn{1}{c}{ Quantity } \\
\hline Energy input & $\mathrm{MJ} \mathrm{ha}^{-1}$ & $321,800.73$ \\
Energy output & $\mathrm{MJ} \mathrm{ha}^{-1}$ & $166,888.80$ \\
Yield & $\mathrm{kg} \mathrm{ha}^{-1}$ & 4500.00 \\
Prunings & $\mathrm{kg} \mathrm{ha}^{-1}$ & 4560.00 \\
Consumed energy intensity & $\mathrm{MJ} \mathrm{m}^{2}$ & 32.21 \\
Produced energy intensity & $\mathrm{MJ} \mathrm{m}^{2}$ & 16.71 \\
Energy use efficiency & & 0.52 \\
Energy productivity & $\mathrm{kg} \mathrm{MJ}^{-1}$ & 0.014 \\
Net energy & $\mathrm{MJ} \mathrm{ha}^{-1}$ & $-154,911.93$ \\
Specific energy & $\mathrm{MJ} \mathrm{kg}^{-1}$ & 71.51 \\
\hline
\end{tabular}

used as farm household fuel wood in the wolfberry planting area.

\section{Energy Use Indicator Analysis in Wolfberry Production Systems}

Results of energy indicators for wolfberry production are given in Table 5. Consumed and produced energy intensities were 32.21 and $16.71 \mathrm{MJ} \mathrm{m}^{-2}$, respectively. Energy use efficiency was 0.26 considering fruits only, and 0.52 taking into account both fruits and pruned wood, indicating that 0.52 energy units were obtained per unit of energy input in the wolfberry production system. Energy use efficiency for organic wolfberry is 1.4 in Aksaray Province of Turkey (Oğuz et al. 2018). Energy ratios of other agricultural products, such as 1.16 for apple (Rafiee et al. 2010), 0.87 for orange (Mohammadshirazi et al. 2012), 0.62 for almond (Beigi et al. 2015), 0.69 for conventional pear production (Liu et al. 2010a), and 0.46 for organic pear (Liu et al. 2010b), have been reported. Hetz (1998) reported that the energy ratio of fruit production ranged between 0.44 and 2.22 in Chile. Low energy use efficiency in the wolfberry planting system resulted from high energy inputs such as electricity consumption, chemical fertilizers, and biocides use. Results show that energy productivity in the wolfberry production system in Jingtai region was $0.014 \mathrm{~kg} \mathrm{MJ}^{-1}$. Energy productivities of other crops have been revealed as $0.42 \mathrm{~kg} \mathrm{MJ}^{-1}$ for apple (Strapatsa et al. 2006), $0.43 \mathrm{~kg} \mathrm{MJ}^{-1}$ for tangerine (Mohammadshirazi et al. 2012), $0.08 \mathrm{~kg} \mathrm{MJ}^{-1}$ for oil olive (Rajaeifar et al. 2014), $0.018-0.025 \mathrm{~kg} \mathrm{MJ}^{-1}$ for various almond varieties (Torki-Harchegani et al. 2015), $0.656 \mathrm{~kg} \mathrm{MJ}^{-1}$ for orange, and $0.555 \mathrm{~kg} \mathrm{MJ}^{-1}$ for lemon (Ozkan et al. 2004). The differences arise from different plants, products, levels of management etc. Net energy was $-154,911.9 \mathrm{MJ} \mathrm{ha}^{-1}$. A negative value of net energy implies wolfberry production is inefficient in energy use, thus indicating that energy is being lost during wolfberry production. A similar issue is also revealed in almond production
Table 6 Total energy input in the form of direct, indirect, renewable, and nonrenewable for wolfberry production

\begin{tabular}{lcl}
\hline Indicators & Quantity $\left(\mathrm{MJ} \mathrm{ha}^{-1}\right)$ & Percentage (\%) \\
\hline Direct energy $^{\mathrm{a}}$ & $256,991.13$ & 79.86 \\
Indirect energy $^{\mathrm{b}}$ & $64,545.60$ & 20.14 \\
Renewable energy $^{\mathrm{c}}$ & $36,957.00$ & 11.48 \\
Nonrenewable energy $^{\mathrm{d}}$ & $284,579.73$ & 88.52 \\
Total energy input & $321,800.73$ & \\
\hline
\end{tabular}

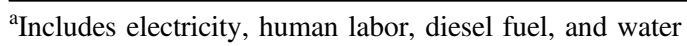

${ }^{\mathrm{b}}$ Includes chemical fertilizer, farmyard manure, chemicals, machinery, and tools

${ }^{\mathrm{c}}$ Includes human labor, farmyard manure, and water for irrigation

${ }^{\mathrm{d}}$ Includes diesel fuel, electricity, chemicals, chemical fertilizer, machinery, and tools

systems in arid Chaharmahal-Va-Bakhtiariprovince, Iran (Beigi et al. 2015). Specific energy refers to how much energy is consumed per unit of harvested products. It was $71.51 \mathrm{MJ} \mathrm{kg}^{-1}$ for wolfberry production in the Jingtai area. Specific energies are $2.66 \mathrm{MJ} \mathrm{kg}-1$ for organic wolfberry in Turkey (O $\breve{g u z}$ et al. 2018), $1.23 \mathrm{MJ} \mathrm{kg}^{-1}$ for kiwifruit (Mohammadi et al. 2010), $60.91-110.31 \mathrm{MJ} \mathrm{kg}^{-1}$ for almond (Torki-Harchegani et al. 2015), and $12.7 \mathrm{MJ} \mathrm{kg}^{-1}$ for oil olive (Rajaeifar et al. 2014) in Iran. By contrast, the specific energy for wolfberry production is higher in the Jingtai region. Total energy input consumed falls into four categories: direct, indirect, renewable, and nonrenewable energy inputs, given in Table 6. The share of direct energy inputs was four times greater than the indirect energy use. And nonrenewable energy use (88.52\%) was far larger than the renewable energy input $(11.48 \%)$. Similar results are found for almond, pear, and cherry (Osman et al. 2018; Kizilaslan 2009). The high portion of nonrenewable and direct energy consumption with poor efficiency means there are serious problems existing in the production systems, not only resulting in environmental impacts, such as pollution, but confronting us with the dilemma of depletion of such invaluable resources. This is, motivated by excessive water use for irrigation induced by irrational water pricing systems, poor irrigation efficiency, and a high rate of chemical use, in particular, excessive fertilizer application.

\section{GHG Emissions and Global Warming Potential (GWP)}

GHG emissions from chemical inputs to the wolfberry cultivation system are given in Table 7. Rates of $\mathrm{CO}_{2}, \mathrm{~N}_{2} \mathrm{O}$ and $\mathrm{CH}_{4}$ emissions were 25881.83, $0.42,0.46 \mathrm{~kg} \mathrm{ha}^{-1}$, respectively, with $\mathrm{CO}_{2}$ making up $99.997 \%$. Wang et al. (2007) revealed a similar pattern in winter wheat-summer maize production system in the North China Plain. In addition, Kramer et al. (1999) found the agricultural products produced $1100 \mathrm{kton} \mathrm{CO}_{2}, 3 \mathrm{kton} \mathrm{N}_{2} \mathrm{O}$ and $0.7 \mathrm{kton}$ 
Table 7 Gaseous emissions $\left(\mathrm{kg} \mathrm{ha}^{-1}\right)$ from chemical sources and their GWP in wolfberry production system

\begin{tabular}{|c|c|c|c|c|}
\hline Inputs & $\mathrm{CO}_{2}$ & $\mathrm{~N}_{2} \mathrm{O}$ & $\mathrm{CH}_{4}$ & $\begin{array}{l}\text { Total GWP } \\
\left(\mathrm{kg} \mathrm{CO}_{2} \text { eq }\right)\end{array}$ \\
\hline 1. Diesel (L) & 569.73 & 0.10 & 0.10 & 602.78 \\
\hline 2. N Fertilizer (kg) & 7171.93 & 0.12 & 0.17 & 7212.07 \\
\hline $\begin{array}{l}\text { 3. Phosphate } \\
\left(\mathrm{P}_{2} \mathrm{O}_{5}\right)(\mathrm{kg})\end{array}$ & 1313.32 & 0.02 & 0.02 & 1318.99 \\
\hline $\begin{array}{l}\text { 4. Potassium } \\
\left(\mathrm{K}_{2} \mathrm{O}\right)(\mathrm{kg})\end{array}$ & 95.67 & 0.00 & 0.00 & 96.64 \\
\hline 5. Electricity $(\mathrm{kW} \mathrm{h})$ & $16,731.19$ & 0.18 & 0.18 & $16,788.16$ \\
\hline Total GHG (kg) & $25,881.83$ & 0.42 & 0.46 & \\
\hline $\begin{array}{l}\text { Total GWP } \\
\left(\mathrm{kg} \mathrm{CO} \mathrm{CO}_{2} \text { eq) }\right.\end{array}$ & $25,881.83$ & 125.22 & 11.59 & $26,018.64$ \\
\hline
\end{tabular}

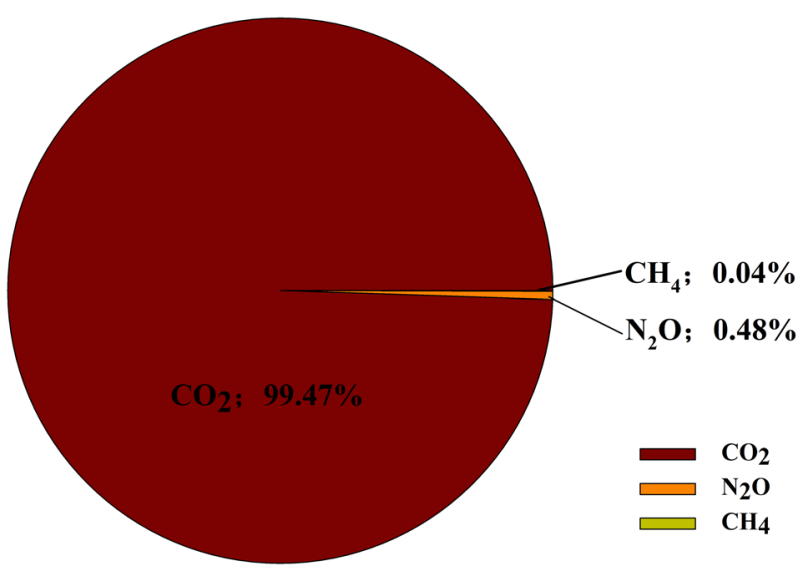

Fig. 1 The share of $\mathrm{CO}_{2}, \mathrm{~N}_{2} \mathrm{O}$, and $\mathrm{CH}_{4}$ of GWP in wolfberry production systems

$\mathrm{CH}_{4}$, respectively, with $\mathrm{CO}_{2}$ being dominant in the Netherlands. In terms of $\mathrm{CO}_{2}$ emissions, the highest share was related to electricity consumption $(64.6 \%)$ followed by $\mathrm{N}$ fertilizer use $(27.7 \%)$ while in the case of $\mathrm{N}_{2} \mathrm{O}$ and $\mathrm{CH}_{4}$ emissions, both showed a similar trend to $\mathrm{CO}_{2}$.

The total GWP in the wolfberry planting system was 26,018.64 $\mathrm{kg} \mathrm{CO}_{2}$ eq ha ${ }^{-1}$ and the shares of $\mathrm{CO}_{2}, \mathrm{~N}_{2} \mathrm{O}$, and $\mathrm{CH}_{4}$ were $99.47 \%, 0.48 \%$, and negligible, respectively, with $\mathrm{CO}_{2}$ being dominant in terms of the greenhouse effect (Fig. 1). The share of GWP of different inputs was $64.52 \%$ for electricity consumption, $27.72 \%$ for $\mathrm{N}$ fertilizer, $5.07 \%$ for phosphate fertilizer, $2.32 \%$ for diesel, and $0.37 \%$ for potassium fertilizer, respectively (Fig. 2). The highest share was highly correlated with electricity consumption for irrigation, followed by $\mathrm{N}$ fertilizer input. The emission of $\mathrm{CO}_{2}$ contributed overwhelmingly to the total GWP of the GHG emissions with both $\mathrm{N}_{2} \mathrm{O}$ and $\mathrm{CH}_{4}$ being rather small. Bakhtiari et al. (2015) revealed electricity had the highest share of GHG emissions in potato production. And the

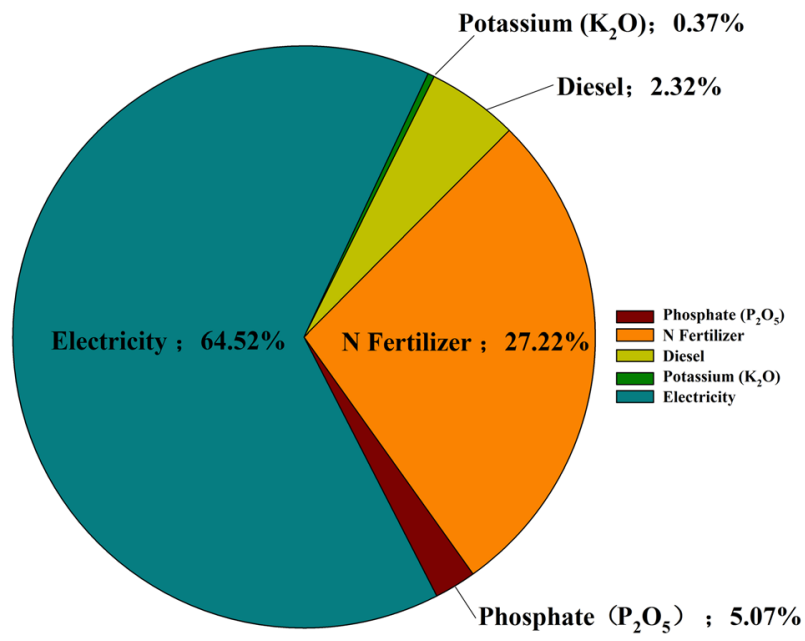

Fig. 2 Share of GWP of different inputs in wolfberry production

greatest share of GWP was also found being related to electricity consumption in an irrigated wheat cultivation system (Yousefi et al. 2015) as well as in cucumber production (Khoshnevisan et al. 2013) while fertilizer application holds the highest portion in the total GHG emissions in oil olive cultivation (Rajaeifar et al. 2014) and soybean farming (Mohammadi et al. 2013).

In the wolfberry production system, the production of wolfberry fruits would cause GWP generation of $5.78 \mathrm{~kg}$ $\mathrm{CO}_{2}$ eq $\mathrm{kg}^{-1}, 2.6 \mathrm{~kg} \mathrm{CO}_{2}$ eq m${ }^{-2}, 0.08 \mathrm{~kg} \mathrm{CO}_{2}$ eq $\mathrm{MJ}^{-1}$ by input energy, or $0.16 \mathrm{~kg} \mathrm{CO}_{2} \mathrm{eq} \mathrm{MJ}^{-1}$ of energy output. The production of $1 \mathrm{~kg}$ of almonds generates $1.5 \mathrm{~kg} \mathrm{CO}_{2}$ eq emissions in California, the USA (Kendall et al. 2015). Pergola et al (2013) reported that the GWP of conventional and organic lemon as well as orange production were 0.12 , $0.04,0.13$, and $0.04 \mathrm{~kg} \mathrm{CO}_{2} \mathrm{eq} \mathrm{kg}^{-1}$, respectively, in Sicily, Italy. GWPs for organic and conventional orange production on small farms ( $<75 \mathrm{ha})$ are 0.084 and $0.112 \mathrm{CO}_{2}$ eq $\mathrm{kg}^{-1}$, respectively, in Brazil (Knudsen et al. 2011). GHG emissions for truly efficient and inefficient orange orchards are $0.075,0.0939$, and $0.126 \mathrm{~kg} \mathrm{CO}_{2} \mathrm{eq} \mathrm{m}^{-2}$, respectively, in Iran (Nabavi-Pelesaraei et al. 2014) while that for apple production system is $0.26 \mathrm{~kg} \mathrm{CO}_{2} \mathrm{eq} \mathrm{m}^{-2}$ in Switzerland (Mouron et al. 2006). In addition, Yousefi et al (2015) reported GWP generation of $1.67 \mathrm{~kg} \mathrm{~kg}^{-1}, 1.17 \mathrm{~kg} \mathrm{~m}^{-2}$, and $0.19 \mathrm{~kg} \mathrm{CO}_{2}$ eq $\mathrm{MJ}^{-1}$ of input energy in irrigated wheat production systems and $0.37 \mathrm{~kg} \mathrm{~kg}^{-1}, 0.07 \mathrm{~kg} \mathrm{~m}^{-2}$, and $0.05 \mathrm{~kg} \mathrm{CO}_{2}$ eq $\mathrm{MJ}^{-1}$ by input energy in rain-fed wheat production as well. Sugar beet production has a GWP generation of 0.024 ton $\mathrm{CO}_{2}$ eq ton ${ }^{-1}$ clean beets harvested in the UK, while it has been estimated to be between 0.174 and 0.093 ton $\mathrm{CO}_{2}$ eq ton ${ }^{-1}$ winter wheat grain in Europe (Tzilivakis et al. 2005). Clearly, the wolfberry production system is not efficient in the use of energy and resources. 


\section{Pathways for Improving Energy use and Abating GHG Emissions}

The threat of climate change has called for the reorientation of development direction. Low carbon agriculture is one of the key sectors to achieve transformation towards low carbon growth and the shift to low carbon farming is a critical step in this connection.

From a policy perspective, innovative policy strategies should be formulated to underpin green growth initiatives. First, smallholder farmland transfer (concentration) should be encouraged through cooperatives, companies, and family farms for scale production. Large farms ( $>5 \mathrm{ha}$ ) uses less chemical fertilizer and consume lower energy for irrigation while the total energy output is higher compared with small farms ( $<1$ ha) and medium farms (1-5 ha) (Pishgar-Komleh et al. 2012). Second, credit (small credit and low interest credit), tax breaks, and subsidies are needed to encourage the shift to low carbon farming.

Efficient transfer of knowledge to farmers through innovative extension systems with the combination of topdown and bottom-up pathways should be carried out and research deliver robust and cost-effective technologies; nonetheless farmers' involvement in them is particularly important.

A seasonal gradient water pricing system, consisting of a basic quota price based on the crop water requirement for the growing season as well as an escalating pricing mechanism for the nongrowing season, should be in place, to leverage substantial water saving.

Greater priority should be given to irrigation for GHG emissions reduction. Irrigation is a carbon-intensive operation. Batty and Keller (1980) reported that energy required for surface irrigation was $3184\left(\mathrm{MJ} \mathrm{ha}^{-1}\right)$ for $0 \mathrm{~m} \mathrm{lift}$, 56,250 $\left(\mathrm{MJ} \mathrm{ha}^{-1}\right)$ for $50 \mathrm{~m}$ lift and 109,317 $\left(\mathrm{MJ} \mathrm{ha}^{-1}\right)$ for $100 \mathrm{~m}$ lift. Increasing irrigation efficiency is vital in reducing GHG emissions and raising energy productivity in wolfberry production in the Jingtai region. Currently extravagant water use for irrigation leads to a lot of water wasted and in turn high electricity consumption for lifting water from the Yellow River. Low irrigation water use efficiency results from inefficient irrigation methods (flooding), high irrigation quotas, and an irrational water pricing mechanism (Wang et al. 2012). New irrigation techniques, for instance, small tube, drip, subsurface drip, etc. should be encouraged by precision technological extension and incentives. Moreover, the use of crop residue and gravel mulching provides another alternative to reduce evaporation from the soil surface, thus, raising water use efficiency and potentially increasing wolfberry yields (Zeng et al. 2013).

For agro-chemicals, synthetic fertilizers in particular nitrogenous fertilizer are a principal source of $\mathrm{CO}_{2}$ and $\mathrm{N}_{2} \mathrm{O}$ emissions (Lal 2004). Further, embodied fossil fuel carbon associated with nitrogen fertilizer accounts for one of the largest energy inputs to agriculture. The chemical fertilizer use rate in Gansu is close to that of developed countries, while the effective utilization rate is about 30\% (Gao 2008). Hence nitrogen fertilizer is a top priority target for GHG reduction. Efforts should be directed to enhance nitrogen fertilizer use efficiency, reducing reliance on chemical fertilizers, and optimizing application rates without negatively affecting productivity and soil fertility. Fertilizer application based on soil nutrient diagnosis, precision placement, and appropriate timing of fertilization (for example, through fertigation by modern irrigation technology), farm manure, $\mathrm{N}$-fixing legume crops, biogas residue, etc. are recommended.

\section{Conclusions}

In the wolfberry systems considered in this study, the largest share of energy inputs was electricity consumption (68.52\%), related to lifting water for irrigation, followed by fertilizer use (11.37\%) and chemicals (5.45\%). Energy ratio was 0.52 with inclusion of pruning wood and the energy productivity was low $\left(0.014 \mathrm{~kg} \mathrm{MJ}^{-1}\right)$. Direct energy inputs were much greater than indirect energy consumption and nonrenewable energy use far larger than the renewable energy input.

Total GHG emissions were $25,882.72 \mathrm{~kg} \mathrm{ha}^{-1}$ with $\mathrm{CO}_{2}$ being overwhelming. And total GWP was $26,018.64 \mathrm{~kg}$ $\mathrm{CO}_{2}$ eq ha ${ }^{-1}$ with the highest share coming from electricity consumption for irrigation. The emission of $\mathrm{CO}_{2}$ contributed most to the GWP.

The production system highly depends on nonrenewable energy $(88.52 \%)$ associated with electricity consumption for irrigation, fertilization, and biocide use and these operations are $\mathrm{C}$ intensive, intensifying GHG emissions.

Irrigation consumes a large amount of energy due to backward irrigation methods, mainly flood irrigation and broader border irrigation. Furthermore the water pricing system leads high irrigation quotas, as a consequent, contributing to increased GHG emissions.

A range of options can be employed to reduce the rate of nonrenewable energy use and mitigate environmental burdens, including conversion to low carbon farming, decreasing nonrenewable energy inputs, and increasing performance of nonrenewable energy inputs. Policy initiatives, including smallholder farmland transfer (concentration) for scale production, credits, tax breaks, and subsidies are strongly recommended to underpin GHG reductions. Efficient transfer of knowledge to farmers and robust and cost-effective technologies formulated by research are essential as well. Innovative water pricing systems, 
improvement of irrigation efficiency by the adoption of new techniques and optimized irrigation norms are crucial. In addition, greater priority should be given to judicious use of chemical fertilizers and biocides with particular attention to reducing the use of synthetic $\mathrm{N}$ fertilizers.

Acknowledgements Funding for this work was provided by the Carbon Benefits Project (CBP) (Sub-award No. G-4280-3), a Global Environmental Facility (GEF) co-financed project and by Natural Science Foundation of China (Grant No. 31660232). We thank Dr William Critchley (Sustainable Land Management Associates Ltd) for valuable comments.

\section{Compliance with Ethical Standards}

Conflict of interest The authors declare that they have no conflict of Interest.

Publisher's note Springer Nature remains neutral with regard to jurisdictional claims in published maps and institutional affiliations.

Open Access This article is distributed under the terms of the Creative Commons Attribution 4.0 International License (http://crea tivecommons.org/licenses/by/4.0/), which permits unrestricted use, distribution, and reproduction in any medium, provided you give appropriate credit to the original author(s) and the source, provide a link to the Creative Commons license, and indicate if changes were made.

\section{References}

Asgharipour MR, Mondani F, Riahinia S (2012) Energy use efficiency and economic analysis of sugar beet production system in Iran: a case study in Khorasan Razavi Province. Energy 44(1):1078-1084

Avraamides M, Fatta D (2008) Resource consumption and emissions from olive oil production: a life cycle inventory case study in Cyprus. J Clean Prod 16(7):809-821

Bakhtiari AA, Hematian A, Moradipour M (2015) Energy, economic and GHG emissions analysis of potato production. J Biodivers Environ Sci 6:2220-6663

Batty JC, Keller J (1980) Energy requirements for irrigation. In: Pimentel D (ed) Handbook of energy utilization in agriculture. CRC, Florida, p 35-44

Beccali M, Cellura M, Iudicello M, Mistretta M (2009) Resource consumption and environmental impacts of the agro-food sector: life cycle assessment of Italian citrus-based products. Environ Manag 43(4):707-24

Beigi M, Torki-Harchegani M, Ghanbarian D (2015) Energy use efficiency and economical analysis of almond production: a case study in Chaharmahal-Va-Bakhtiari province, Iran. Energy Efficiency 91(10):1-10

Cao ZF (2014) Status quo and development of wolfberry industry in Gansu. Agric Sci-Technol Inf 6:41-43

Cerutti AK, Beccaro GL, Bruun S, Bosco S, Donno D, Notarnicola B, Bounous G (2014) Life cycle assessment application in the fruit sector: state of the art and recommendations for environmental declarations of fruit products. J Clean Prod 73(12):125-135

Cervinka V (1980) Fuel and energy efficiency. In: Pimental D (ed) Handbook of energy utilization in agriculture. CRC Press, Boca Raton FL, p 15-21

Cui SH, Shi YL, Groffman PM, Schlesinger WH, Zhu YG (2013) Centennial-scale analysis of the creation and fate of reactive nitrogen in China (1910-2010). Proc Natl Acad Sci USA 110:2052-2057

Deng CY (2014) Research on developing low-carbon agriculture in Gansu province. Dissertation, Northwest Normal University

Dwivedi P, Spreen T, Goodrich-Schneider R (2012) Global warming impact of Florida's not-from-concentrate (NFC) orange juice. Agric Syst 108:104-111

Fan H, Li Y, Cong F, Huo P, Wang K (2016) Energy-use efficiency and economic analysis of sugar beet production in China: a case study in Xinjiang province. Sugar Tech 18(3):309-316

FAO (2012) Energy-smart food at FAO: an overview. The FAO Technical Papers: http://www.fao.org/docrep/015/an913e/an913e00.htm

Esengun K, Gündüz O, Erdal G (2007) Input-output energy analysis in dry apricot production of Turkey. Energy Convers Manag 48:592-598

FAOSTAT (2014) Emissions of methane and nitrous oxide produced from agricultural activities. FAOSTAT. http://faostat3.fao.org/fa ostat-gateway/go/to/browse/G1/*/E. Accessed July 2014

Gao S (2008) Status and sustainable development of Gansu agriculture. Folkways 8:12

Ghatrehsamani S, Ebrahimi R, Kazi SN, Badry AB, Sadeghinezhad E (2016) Optimization model of peach production relevant to input energies-Yield function in Chaharmahal Va Bakhtiari Province, Iran. Energy 99:315-321

Gundogmus E (2013) Modeling and sensitivity analysis of energy inputs for walnut production. Actual Probl Econ 2:188-197

He CY, Zhang GZ, Li SC (2011) Investigation and analysis on the fertilization management and soil nutrients of Lycium barbarum in Yellow River irrigation area of central Gansu. J Gansu Forestry Sci Technol 36(2):6-10

Hetz EJ (1998) Energy utilization in fruit production in Chile. Agric Mechanization Asia Afr Lat Am 29(2):17-20

Iriarte A, Rieradevall J, Gabarrell X (2010) Life cycle assessment of sunflower and rapeseed as energy crops under Chilean conditions. J Clean Prod 18:336-345

IPCC (1995) Climate change, the science of climate change. In: Houghton JT, Meira Filho LG, Callander BA, Harris N, Kattenberg A, Maskell K (eds) Intergovernmental panel on climate change. Cambridge University Press, Cambridge

Jiao XQ, Lyu Y, Wu X, Li H, Cheng LY, Zhang CC, Yuan LX, Jiang RF, Jiang BW, Rengel Z, Zhang FS, Davies WJ, Shen JB (2016) Grain production versus resource and environmental costs: towards increasing sustainability of nutrient use in China. J Exp Bot 67(17):4935-4949

Kendall A, Marvinney E, Brodt S, Zhu W (2015) Life cycle-based assessment of energy use and greenhouse gas emissions in almond production, part 1: analytical framework and baseline results. J Ind Ecol 19(6):1423-1430

Khan S, Khan MA, Hanjra MA, Mu J (2009) Pathways to reduce the environmental footprints of water and energy inputs in food production. Food Policy 34:141-149

Khoshnevisan B, Rafiee S, Omid M, Mousazadeh H (2013) Reduction of $\mathrm{CO}_{2}$ emission by improving energy use efficiency of greenhouse cucumber production using DEA approach. Energy $55: 676-682$

Kizilaslan H (2009) Input-output energy analysis of cherries production in Tokat Province of Turkey. Appl Energy 86(7-8):1354-8

Knudsen MT, Almeida GFD, Langer V, Abreu LSD, Halberg N (2011) Environmental assessment of organic juice imported to Denmark: a case study on oranges (Citrus sinensis) from Brazil. Org Agriculture 1(3):167-185

Kramer KJ, Moll HC, Nonhebel S (1999) Total greenhouse gas emissions related to the Dutch crop production system. Agriculture Ecosyst Environ 72:9-16

Külekci M, Aksoy A (2013) Input-output energy analysis in pistachio production of turkey. Environ Prog Sustain Energy 32:128-133 
Lal R (2004) Carbon emission from farm operations. Environ Int 30 (7):981-90

Leggett JA (2011) China's greenhouse gas emissions and mitigation policies, CRS report for Congress. Congressional Research Service. https://fas.org/sgp/crs/row/R41919.pdf

Li XD, Kang TL, Liu XZ, Cao ZF, Wu YA (2017) Development suggestions and status of wolfberry industry in Gansu province. Gansu Agriculture Sci Technol 1:65-69

Li Z, Zhang CX, Li M, Xu K, Li EM, Cheng CG (2010) Review of characteristics of carbon circle in orchard ecosystem. Liaoning Agric Sci 6:28-31

Lin JY, Hu YC, Cui SH, Kang JF, Xu LL (2015) Carbon footprints of food production in China (1979-2009). J Clean Prod 90:97-103

Liu Y, Langer V, Høgh-Jensen H, Egelyng H (2010a) Life cycle assessment of fossil energy use and greenhouse gas emissions in Chinese pear production. J Clean Prod 18(14):1423-1430

Liu YX, Langer V, Høgh-Jensen H, Egelyng H (2010b) Energy use in organic, green and conventional pear producing systems-cases from China. J Sustain Agriculture 34:630-646

Liu ZW (2011) The woody plant calorific value and anatomic structure comparison study. Master's thesis, Shandong University

Michos MC, Mamolos AP, Menexes GC, Tsatsarelis CA, Tsirakoglou VM, Kalburtji KL (2012) Energy inputs, outputs and greenhouse gas emissions in organic, integrated and conventional peach orchards. Ecol Indic 13(1):22-28

Ming Y, Cheng K, Qian Y, Yu Y, Rees RM, Pan GX (2015) Farm and product carbon footprints of China's fruit production-life cycle inventory of representative orchards of five major fruits. Environ Sci Pollut Res 6(9):1-11

Mohammadi A, Rafiee S, Jafari A et al. (2013) Potential greenhouse gas emission reductions in soybean farming: a combined use of life cycle assessment and data envelopment analysis. J Clean Prod 54(54):89-100

Mohammadi A, Rafiee S, Mohtasebi SS, Rafiee H (2010) Energy inputs-yield relationship and cost analysis of kiwifruit production in Iran. Renew Energy 35(5):1071-1075

Mohammadshirazi A, Akram A, Rafiee S, Avval SHM, Kalhor EB (2012) An analysis of energy use and relation between energy inputs and yield in tangerine production. Renew Sustain Energy Rev 16(16):4515-4521

Mouron P, Nemecek T, Scholz RW, Weber O (2006) Management influence on environmental impacts in an apple production system on Swiss fruit farms: combining life cycle assessment with statistical risk assessment. Agriculture Ecosyst Environ 114 (2):311-322

Mousaviavval SH, Rafiee S, Jafari A, Mohammadi A (2011) Energy flow modeling and sensitivity analysis of inputs for canola production in Iran. J Clean Prod 19(13):1464-1470

Nabavi-Pelesaraei A, Abdi R, Rafiee S, Mobtaker HG (2014) Optimization of energy required and greenhouse gas emissions analysis for orange producers using data envelopment analysis approach. J Clean Prod 65:311-317

Nayak D, Saetnan E, Cheng K et al. (2015) Management opportunities to mitigate greenhouse gas emissions from Chinese agriculture. Agriculture Ecosyst Environ 209:108-124

Nemecek T, Dubois D, Huguenin-Elie O et al. (2011) Life cycle assessment of Swiss farming systems: I. Integrated and organic farming. Agric Syst 104(104):217-232

Osman G, Erdoğan O, Oğuz HI, Baran MF (2018) Studies of energy use efficiency on fruit production. Erwerbs-Obstbau 61(1):47-51

Oğuz HI, Gökdoğan O, Baran MF (2018) Determination of energy balance in organic wolfberry (Lycium barbarum $L$.) production in Turkey. Erwerbs-Obstbau 61(25):61-66

Ozkan B, Kurklu A, Akcaoz H (2004) An input-output energy analysis in greenhouse vegetable production: a case study for Antalya region of Turkey. Biomass-Bioenergy 26:189-95
Peng WE (2011) Sustainable development measures for water conservation in the Jingtai irrigated region. Water Sav Irrig 7:58-59

Pergola M, D'Amico M, Celano G, Palese AM, Scuderi A, Vita GD, Pappalardo G, Inglese P (2013) Sustainability evaluation of Sicily's lemon and orange production: an energy, economic and environmental analysis. J Environ Manag 128:674-682

Pishgar-Komleh SH, Ghahderijani M, Sefeedpari P (2012) Energy consumption and $\mathrm{CO}_{2}$ emissions analysis of potato production based on different farm size levels in Iran. J Clean Prod 33:183-191

Rafiee S, Avval SHM, Mohammadi A (2010) Modeling and sensitivity analysis of energy inputs for apple production in Iran. Energy 35:3301-3306

Rajaeifar MA, Akram A, Ghobadian B, Rafiee S, Heidari MD (2014) Energy-economic life cycle assessment (LCA) and greenhouse gas emissions analysis of olive oil production in Iran. Energy 66:139-149

Sheng YL, Su HB (2011) An assessment of technology and benefits from chicken grazing in a wolfberry plantation. Gansu Sci Technol 27(5):155-156

Strapatsa AV, Nanos GD, Tsatsarelis CA (2006) Energy flow for integrated apple production in Greece. Agriculture Ecosyst Environ 116(3-4):176-180

Su HR (2012) A strategy investigation on sustainable development of China's deciduous fruit production. Deciduous Fruit 44(1):1-4

Tabatabaie SMH, Rafiee S, Keyhani A (2012) Energy consumption flow and econometric models of two plum cultivars productions in Tehran Province of Iran. Energy 44:211-216

Tabatabaie SMH, Rafiee S, Keyhani A, Heidari MD (2013) Energy use pattern and sensitivity analysis of energy inputs and input costs for pear production in Iran. Renew Energy 51:7-2

Taylor AEB, O'Callaghan PW, Probert SD (1993) Energy audit of an English farm. Appl Energy 44:315-335

Tilman D, Balzer C, Hill J, Befort BL (2011) Global food demand and the sustainable intensification of agriculture. Proc Natl Acad Sci USA 108:20260-20264

Torki-Harchegani M, Ebrahimi R, Mahmoodi-Eshkaftaki M (2015) Almond production in Iran: an analysis of energy use efficiency (2008-2011). Renew Sustain Energy Rev 41(41):217-224

Tzilivakis J, Warner DJ, May M, Lewis KA, Jaggard K (2005) An assessment of the energy inputs and greenhouse gas emissions in sugar beet (Beta vulgaris) production in the UK. Agriculture Syst 85:101-119

Uhlin H (1998) Why energy productivity is increasing: an I-O analysis of Swedish agriculture. Agric Syst 56:443-465

Vermeulen S, Campbell B, Ingram JSI (2012) Climate change and food systems. Annu Rev Environ Resour 37:195-222

Wang MX, Wu WL, Liu WN, Bao YH (2007) Life cycle assessment of the winter wheat-summer maize production system on the North China Plain. Int J Sustain Dev World Ecol 14 (4):400-407

Wang YL, Zhao CY, Ma QL, Li YK, Jing HJ, Sun T, Milne E, Easter M, Paustian K, Au Yong HW, McDonagh J (2015) Carbon benefits of wolfberry plantation on secondary saline land in Jingtai oasis, Gansu-a case study on application of the CBP model. J Environ Manag 157:303-310

Wang YZ, Yao XZ, Fan SZ, Lu YJ, Li JR, Chen CX (2012) Current situation and consideration on water conservation on farmland in Jingtai County. Gansu. Agriculture 21:83-85

Wang ZB, Zhang HL, Lu XH et al. (2015) Lowering carbon footprint of winter wheat by improving management practices in North China Plain. J Clean Prod 112:149-157

$\mathrm{Xu}$ AL, Zhou JQ, Wang YN (2007) Study on determination of combustion heat of matrimony vine. Chin J Inf Traditional Chin Med 14(8):44-45 
Yang J, Chen B (2013) Carbon footprint estimation of Chinese economic sectors based on a three-tier model. Renew Sustain Energy Rev 29(29):499-507

Yang XL, Gao WS, Zhang M, Chen YQ, Sui P (2014) Reducing agricultural carbon footprint through diversified crop rotation systems in the North China Plain. J Clean Prod 76:131-139

Yildiz T, Hazneci K, Hazneci E, Ozkaraman F (2016) The energy use efficiency determinants of peach production in Samsun Province of Turkey. Fresenius Environ Bull 25:4685-4693

Yin J, Gao Z, Zhang B, Zhen Y (1998) A study of the energy conversion system in farming. J Shanxi Agric Univ 18(2):95-98

Yousefi M, Damghani AM, Khoramivafa M (2015) Comparison greenhouse gas (GHG) emissions and global warming potential
(GWP) effect of energy use in different wheat agro-ecosystems in Iran. Environ Sci Pollut Res 23(8):7390-7397

Zeng XC, Li WH, Qiang SC, Pan JM, Zhang YL, Qi GP (2013) Effects of straw mulch and irrigation on growth and water use efficiency of Lycium. Agric Res Arid Areas 31(3):61-66

Zhang GZ, Wang YK, Fan H, Qi GP, He CY, Cai GJ (2010) The effect of water retention on different covering materials and the influence of effect the growth and development of medlar. Agric Res Arid Areas 28(2):49-52

Zhang L, Li MZ, Yang B (2010) Outstanding problems and development suggestions of industrialization development of Lycium chinensis in Gansu province. J Gansu Forestry Sci Technol 35 (1):57-60 